\title{
Entangled fates of holobiont genomes during invasion: nested bacterial and host diversities in Caulerpa taxifolia
}

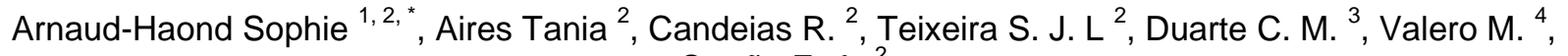 \\ Serrão E. A. ${ }^{2}$
}

${ }^{1}$ IFREMER, UMR MARBEC, Station de Sète, Avenue Jean Monnet, CS 30171, 34203 Sète Cedex \& OREME - Station Marine; Université Montpellier; 2 rue des Chantiers - CC 9900934200 Sète, France

${ }^{2}$ CCMAR-CIMAR, MAREE; Universidade do Algarve Campus de Gambelas; 8005 - 139 FARO,

Portugal

${ }^{3}$ RSRC (Red Sea Research Center), Building 2, Level 3, Room 3219; King Abdullah University of

Science and Technology (KAUST); Thuwal 23955-6900 ,Kingdom of Saudi Arabia

${ }^{4}$ UMI EBEA 3614, Evolutionary Biology and Ecology of Algae; CNRS, Sorbonne Universités, UPMC, PUCCh, UACH, Station Biologique de Roscoff, CS 90074; Place Georges Teissier 29688 Roscoff

Cedex ,France

*Corresponding author : Sophie Arnaud-Haond, email address : sarnaud@ifremer.fr

\begin{abstract}
:
Successful prevention and mitigation of biological invasions requires retracing the initial steps of introduction, as well as understanding key elements enhancing the adaptability of invasive species. We studied the genetic diversity of the green alga Caulerpa taxifolia and its associated bacterial communities in several areas around the world. The striking congruence of $\alpha$ and $\beta$ diversity of the algal genome and endophytic communities reveals a tight association, supporting the holobiont concept as best describing the unit of spreading and invasion. Both genomic compartments support the hypotheses of a unique accidental introduction in the Mediterranean and of multiple invasion events in Southern Australia. In addition to helping with tracing the origin of invasion, bacterial communities exhibit metabolic functions that can potentially enhance adaptability and competitiveness of the consortium they form with their host. We thus hypothesize that low genetic diversities of both host and symbiont communities may contribute to the recent regression in the Mediterranean, in contrast with the persistence of highly diverse assemblages in southern Australia. This study supports the importance of scaling up from the host to the holobiont for a comprehensive understanding of invasions.
\end{abstract}

\section{Introduction}

Biological invasions are both a consequence and an active part of global change (McNeely 2006; Vitousek et al. 1997), and although the generalization of their negative impact is controversial, some introduced species have acute impacts on native communities. The underlying causes for 
the invasive behavior of some species when introduced to new environments is a central question that has yet to be fully resolved (Sakai et al. 2001). In addition to some specific life-history traits prevalent in invasive species, such as clonality or selfing (Barrett 2015; Odom \& Walters 2014), the genetic diversity of introduced pools (Roman \& Darling 2007), as well as the alteration of biotic interactions, can influence the invasive behavior of numerous introduced species. Among the best known biotic interactions that may affect the potential of introduced species to become invasive are those related to the "enemy release hypothesis" (REH; Mitchell et al. 2006; Mitchell \& Power 2003; Torchin et al. 2003; Torchin \& Mitchell 2004). The ERH postulates that the absence of co-adapted predators, parasites or pathogens allows introduced species to avoid losses and allocate more resources to growth and reproduction in introduced ranges over ecological time scales, which may lead to the "evolution of improved competitive ability" over evolutionary time scales (EICA; Blossey \& Notzold 1995).

Most empirical tests of invasive theories have focused on detrimental biotic interactions (mostly predation, parasitism and competition), whereas positive biotic interactions have received much less attention (but see Chisholm et al. 1996; Mitchell et al. 2006; Richardson et al. 2000). A poorly understood but likely very important biotic interaction is symbiosis with prokaryotes, despite reports suggesting that such microorganisms can play a determinant role (Klock et al. 2015; Mitchell et al. 2006; Richardson et al. 2000; Rodriguez-Echeverria 2010). Three main hypotheses have been proposed to describe the possible positive relationship between eukaryotic hosts and mutualists during an invasion (Klock et al. 2015). The Generalist Host Hypothesis proposes that invasive species may be relative generalist hosts (Parker 2001; RodriguezEcheverria et al. 2011), the Enhanced Mutualism Hypothesis that new mutualism is established

This article is protected by copyright. All rights reserved. 
between introduced and native species (Richardson et al. 2000), and the Accompanying Mutualist Hypothesis that invasive hosts are co-introduced with mutualistic symbionts (Rodriguez-Echeverria et al. 2011).

Here, we test these hypotheses by simultaneously addressing the evolution of the genetic pool of an invasive species and that of its associated bacterial flora, from its native and invasive ranges. Our goal is to ascertain the most likely path and mechanism of introduction while screening for possible interactions between host and associated bacteria that may help in understanding their success as invasive species. A good candidate for exploring these relationships and their potential influence on an invasive trajectory is the complex of Caulerpa species and their associated bacterial fauna (Delbridge et al. 2004; Meusnier et al. 2001). The tropical green alga C. taxifolia was first discovered in 1984 in the Mediterranean Sea (Meinesz \& Hesse 1991), where it spread to form dense meadows of large, cold-adapted, turbid-water thalli. These contrast sharply with the isolated and patchy aggregations of warm-adapted, clear-water thalli with small and delicate architecture observed in its native area of Queensland, in northeastern Australia (Fama et al. 2002; Meusnier et al. 2002). The sudden Mediterranean spread resulted in important detrimental effects including displacement of Mediterranean species from areas where $C$. taxifolia formed dense populations (BellanSantini et al. 1996; Boudouresque et al. 2009; Francour et al. 1995; Williams 2007). This was the case for the seagrass Posidonia oceanica, the foundation species of the most important (in terms of cover, biomass and biodiversity) Mediterranean coastal ecosystem, which is experiencing severe declines (Marbà et al. 2014; Marba \& Duarte 2010). A distinct wave of invasion by C. taxifolia was recorded in the region of New South Wales (NSW) in southeastern Australia in the early 2000s (Millar 2004; Schaffelke

This article is protected by copyright. All rights reserved. 
et al. 2002), inducing similar pervasive effects on native species (Byers et al. 2010; but see Glasby 2013; Wright et al. 2007). More recently, an invasion was triggered in San Diego (California, USA), but it was successfully halted because it was detected early enough to be controlled (Anderson 2005).

In this study, our aims are (i) comparing bacterial $\alpha$-diversity in invaded versus native ranges and their change during the course of invasion; (ii) assessing the strength of the relationship between the algae and the bacterial OTUs that characterize its endophytic communities; (iii) using the information from host genetics and bacterial community profiles to deliver insights regarding the putative number of introduction events and their origin; and iv) examining the functions of the most relevant bacterial lineages compared to habitat modifications associated with invasion by C. taxifolia, to inform hypotheses on how endophytic bacteria might have influenced the switch of C. taxifolia from an introduced to an invasive alga. To achieve these goals, we estimated the host and bacterial diversity of $C$. taxifolia from the native Queensland and the introduced NSW and Mediterranean regions (Fig. 1) to compare the genetic diversity of both compartments in native versus invasive populations.

\section{Materials and Methods}

\section{Sampling and DNA extraction}

We focused on three areas: the native Queensland (QLD) and the invaded coasts of the Mediterranean (MED) and New South Wales (NSW). In invasive areas, samples were collected (Fig. 1) in 2009 in the Mediterranean (Tunis and Villefranche, MED) during Northern Hemisphere summer (July to August), and in 2010 in Australia (New South Wales, NSW: Port

This article is protected by copyright. All rights reserved. 
Jackson, Lake Conjola, Narrawallee, Burrill Lake) during the Southern Hemisphere summer (January-February). In the Northern part of its native area (Queensland, QLD), Caulerpa taxifolia was collected in April 2010 along the beach of Kissing Point, a beach near Townsville, here referred to as Townsville.

For host population genetics, a total of 236 sampling units (SUs, composed of several fronds linked together by the same stolon and sampled at least 1-2 m apart from each other) were collected from 8 localities in Australia and from 3 in the Mediterranean (Fig. 1; Table 1), with a sampling density of approximately 30 sampling units (SUs) within approximately $1-2 \mathrm{~km}^{2}$. Additionally, historical samples that were silica-dried, and thus could only be used for host population genetics, were added: one sample from the Oceanographic Museum of Monaco, two from the San Diego 'aborted' invasion (Anderson 2005), and one from a native area of the Pacific (Tahiti), together with 19 sampling units from the native area of Brisbane (QLD), four samples collected in 1999 in Kelso Reef (QLD) and in Croatia (MED), all from previous studies (Jousson et al. 1998; Meusnier et al. 2001; Meusnier et al. 2004).

Samples for microsatellite genotyping were preserved either frozen $\left(-20^{\circ} \mathrm{C}\right)$, in silica gel, or in CTAB (cetyltrimethyl ammonium bromide) buffer until extraction in the laboratory. Total genomic DNA was extracted using the CTAB method (Doyle \& Doyle 1987).

For bacterial communities, a total of 3 to 6 disinfected SUs yielding a threshold concentration above $50 \mathrm{ng} \mu \mathrm{L}^{-1}$ were amplified and sequenced per location. For each location, a sample of sediment and 3 non-disinfected SUs were also analyzed as a control for endophytes versus whole communities. These were picked from a collection of sample of 15 fresh SUs taken from from

This article is protected by copyright. All rights reserved. 
each locality (Table S2, Supplementary material). Those 15 SUs were subdivided into two subsets: one with the DNA extracted immediately from one portion (disinfection control) and one after a previously reported disinfection pre-treatment (Aires et al. 2012). Sediment sampled in the same locations wasfrozen $\left(-80^{\circ} \mathrm{C}\right)$ until DNA extraction. Bacterial DNA extraction was performed using the FastDNA® SPIN Kit for Soil (MP Biomedicals, LLC).

\section{Population genetics analysis}

Eight microsatellite loci specifically developed for C. taxifolia were amplified from 195 SUs (Arnaud-Haond et al. 2013), and fragments were separated on an ABI 3130 XL automatic sequencer (Applied Biosystems, Foster City, CA, USA).

Due to the partial clonality of Caulerpa taxifolia, multi-locus genotypes (MLGs) of each sampling unit were used to infer their membership in clonal lineages based on their probability of multiple occurrence through independent sexual events (Arnaud-Haond et al. 2005; ArnaudHaond et al. 2007). Genotypic diversity was assessed (see Table 1) using the main indices summarized by Arnaud-Haond et al. (2007) and computed in GenClone (Arnaud-Haond \& Belkhir 2007). Genetic differentiation was then estimated through $\mathrm{F}_{\mathrm{ST}}$ estimates (Belkhir et al. 1996-2001) and network analysis based on allele sharing distance as previously proposed for clonal organisms (Bowcock et al. 1994; Kivelä et al. 2015; Moalic et al. 2011; Rozenfeld et al. 2008) and detailed in the Supplementary material.

This article is protected by copyright. All rights reserved. 


\section{Microbial community analysis}

Amplification of the 16Sr V3-V4 DNA region of amplicons was performed using barcoded fusion primers (V3 forward: 16Sar, V4 reverse: 16Sbr) with Roche-454 A Titanium sequencing adapters with a unique 8 bp key-tagged universal primers (Wang \& Qian 2009). Amplicons were analyzed using tagged pyrosequencing (GS FLX Titanium, 454-Life Sciences-Roche technology $\left.{ }^{\circledR}\right)$.

The data analyses are detailed in the Supplementary material. The analyses were performed using the QIIME v. 1.6.0 pipeline (Caporaso et al. 2010) to filter datasets, remove chimeras, perform clustering (at the $97 \%$ identity level), and infer taxonomy using BLAST with an $80 \%$ confidence threshold and a minimum e-value threshold of 10-3 (default value). $\alpha$-Diversity was estimated both for each SU and within each location by clustering replicates using Shannon's diversity index, Chao 1 richness and number of unique OTUs estimates to estimate the coverage of the community reached via the sequencing effort performed. Estimates were standardized (for the disinfected samples) to the smallest number of sequences obtained in the sample delivering the lowest yield. $\beta$-Diversity was assessed using a weighted UniFrac algorithm, taking into account both the phylogenetic distance and the frequency of phylotypes among samples. The differentiation and clustering of communities were illustrated through Principal coordinate analysis (PCoA) plots and network analysis, and their significance was tested using ANOSIM based on Bray Curtis dissimilarity.

This article is protected by copyright. All rights reserved. 


\section{Congruence between host and bacterial community patterns}

The relationship between the levels of the $\alpha$-diversity of the host (clonal and genetic diversities through $\mathrm{R}, \hat{\mathrm{A}}$ and $\mathrm{H}_{\mathrm{nb}}$ ) and bacterial (endophytic communities, through the standardized number of estimated OTUs) compartments. As for $\beta$-diversity, a Mantel test was performed to test for the relationship between patterns of divergence among locations for both compartments (Fst versus Bray-Curtis values).

\section{Results}

\section{Population genetics of the host}

A total of 54 distinct multi-locus genotypes (MLGs; Table 1) were identified with 8 microsatellites, with few sampling units (SUs) sharing identical MLGs in the native range of Queensland (particularly Townsville and Kelso Reef, with slightly more identical MLGs observed in Brisbane), whereas clonal dominance was clear in the invaded ranges. Several distinct dominant MLGs were discriminated in NSW. In contrast, the Mediterranean sites were characterized by a core of nearly identical MLGs differing at only one locus (GE3) (Table 1, Fig. 2). The MLG characterizing the aquarium strain was retrieved in 2010 in Villefranche and Tunis (circled in red in Fig. 2), while the slightly different and most common MLG sampled in those two locations corresponds to the one isolated during the successfully aborted invasion in California (Fig. 2).

Both clonal diversity $(\mathrm{G}, \mathrm{R})$ and evenness (Simpson $\mathrm{D}^{*}$, Pareto $\beta$ ), as well as genetic diversity (heterozygosity and allelic richness), were highest in the native area of Queensland and lowest in the Mediterranean, with a wide range of intermediate values in NSW (Table 1, Table S1, Fig. 2).

This article is protected by copyright. All rights reserved. 
The network of MLGs analyzed at the percolation threshold $(\mathrm{Dpe}=1.25)$ showed a high and significant value of clustering $(<\mathrm{C}>=0.8)$, illustrating the significant regional grouping of MLGs (Fig. 2, Queensland, NSW and the Mediterranean; Table S6), with two distant clusters corresponding to North and South locations in Queensland and the four samples from Kelso Reef appearing as intermediate among those.

The unique core cluster of Mediterranean MLGs appeared closer to one MLG from Brisbane than to those from the northern part of the native range (Kelso Reef and Townsville). Finally, a large cluster grouped all samples from the invaded range of New South Wales closer to samples from Townsville and Kelso Reef than to those from Brisbane, except for the two MLGs detected in Port Jackson that belonged to the Townsville cluster. In contrast, the large South Australian cluster formed a cohesive and distinct assemblage of closely related MLGs with a core MLG found in all three locations (Lake Conjola, Burrill Lake and Narrawallee), although some unique and divergent MLGs were also detected in Narrawallee.

\section{Endophytic microbial communities}

$\alpha$-Diversity analysis

The $\alpha$-diversity (standardized for the smallest number of sequences) for the endophytic community ranged widely, from 29 in a SU from the Mediterranean to 694 in an SU from NSW, and higher values were usually observed for non-disinfected samples (i.e., endophytic and epiphytic strains, Table S2). When pooling replicates to obtain estimates of diversity per location, the communities with highest diversity were found in Queensland (Townsville) and NSW (Narrawallee; Table S3, Supplementary material).

This article is protected by copyright. All rights reserved. 


\section{ß-Diversity}

A clear and significant differentiation of disinfected communities versus non-disinfected and sediment communities was supported by ANOSIM $(p<0.001)$ and illustrated by the PCoA projection (Fig. 33), with a lower but significant differentiation between the pool of nondisinfected SUs and that of the sediment ( $\mathrm{p}<0.01$, Table S4). The differentiation between disinfected communities and the cluster of non-disinfected and sediment communities was also reflected in differences in frequencies of the OTUs at the class and order levels (Fig. S1, Fig. S2).

The disinfected SUs from Australia and the Mediterranean form two differentiated clusters that are closer to each other than to 'environmental' samples (Fig. 3a). Mediterranean endophytic communities segregated significantly $(\mathrm{p}<0.05$, Supplementary Table S5) from all Australian ones (Figs. 2b, 3a and 3b). Two groups of Australian SUs emerged, corresponding to localities from the Australian invaded and native ranges, except for the SUs sampled in Port Jackson (NSW), which clustered together on PCoA with those from Townsville (QLD) in the native area (Figs. 2b and 3b). Except for this case, and for Burrill Lake, for which the lack of replication did not allow statistical analysis, all samples showed statistically significant differentiation among regions (QLD, NSW, Med, $\mathrm{p}<0.05, \mathrm{R}=0.86$ ), while no heterogeneity among localities was detected within each invaded region (Med, NSW without Port Jackson; $p>0.05$; Fig. 3b; Table S5).

\section{Bacterial community characterization}

From the phylum Proteobacteria, the most represented are Alpha-, Beta- and

Gammaproteobacteria. The former and the latter are common to all regions and treatments, while OTUs belonging to the class Betaproteobacteria are characteristic of disinfected samples

This article is protected by copyright. All rights reserved. 
(endophytic communities; Fig. S1). Burkholderiales is the most widely represented order of this class, and it is highly represented in the Mediterranean Sea, Townsville and Port Jackson and absent in other samples from NSW (Fig. S5). A mirror image was observed for Rhizobiales, all disinfected SUs being shared throughout the Australian NSW invasive range except those from Port Jackson, which clustered overall with the SU from the native range of Townsville (Fig. 2b, Fig. 3b). For Gammaproteobacteria, specifically the order Pseudomonadales, sequences from SUs sampled in the native areas, the Mediterranean, and Port Jackson often shared OTUs absent from the cluster samples from NSW, which in turn exhibited a wide diversity of characteristic OTUs (Fig. S4).

The networks of haplotypes (Fig. 4) showed either a complete admixture of haplotypes independently of their geographical origin (for the most common OTUs within Burkholderiales, assigned by BLAST to Alicycliphilus denitrificans), or geographic clustering of the most common OTUs (within Pseudomonadales, assigned to Acinetobacter sp). In addition to being rare in NSW (except Port Jackson), “Acinetobacter-like” OTUs from NSW were also very distinct : only the SUs from Port Jackson one SU from Narrawallee share haplotypes in common with the Mediterranean and Queensland areas. Interestingly, this SU from Narrawallee which bacterial communities departs from the most ones characterized in NSW is also the SU having a genome most distant from all other NSW SUs (Fig. 3b).

\section{Congruence between host and Bacterial community patterns}

This study shows a striking congruence between the levels of diversities (both $\alpha$ and $\beta$ ) of the genomic and bacterial compartments of the native and invaded ranges (Table 1, Fig. 2). A significant relationship was detected between $\alpha$-diversities (Figure S6) of the host genome (as

This article is protected by copyright. All rights reserved. 
estimated through heterozygosity: $r^{2}=0.63 \& p=0.03$, and standardized allelic richness $r^{2}=0.61 \&$ $\mathrm{p}=0.04$ ) and the $\alpha$-diversity of endophytic communities (the standardized number of estimated OTUs), whereas no relationship was detected with clonal diversity R (as estimated through R: $\mathrm{r}^{2}=0.13, \mathrm{p}=0.43$ ). Similarly, the Mantel test performed to test for the relationship between patterns of $\beta$-diversity among location for the population genetics of the algae (Fst values) and for their endophytic communities (Bray-Curtis distance) showed a significant relationship $(\mathrm{Z}=21.7, \mathrm{p}=0.04)$, and the clusters appearing below the percolation thresholds for both the host and the bacterial networks showed a high congruence (Table S6). Together with the specific nature of endophytic communities compared to environmental controls (Fig. 3), this reveals a concordant signature of the invasion process on both the host and endophyte genomes.

\section{Discussion}

Difference in invasion scenarios were described and explained by the interaction of migration with other ecological and/or evolutionary forces (in particular life history traits and mating system) during the invasion process (Facon et al. 2006; Puth \& Post 2005; Rius et al. 2014).This study illustrates two contrasted scenario of invasion for the same species, supporting a unique introduction of a pre-adaptated genotype reproducing clonally in the Mediterranean sea versus multiple introductions of different genotypes in NSW. The magnitude and distribution of the diversity of both Caulerpa taxifolia and the bacterial community in two distinct invaded areas provide remarkably coherent and relevant information suggesting that the holobiont concept may allow to better understand the interaction of migration with ecological and evolutionary forces during this process.

This article is protected by copyright. All rights reserved. 


\section{Aquarium origin and clonal spread in the Mediterranean versus multiple introductions in}

\section{New South Wales}

The comparison of the Mediterranean and NSW invasion cases provides contrasting patterns that strongly suggest signatures of unique versus multiple introductions, respectively. The hypothesis of a unique event of release of Caulerpa taxifolia from the Monaco aquarium into the Mediterranean was first published by Meinesz \& Boudouresque 1996. This hypothesis was confirmed by phylogeographic studies through Internal Transcribed Spacer (ITS) sequencing (Jousson et al. 1998; Meinesz \& Boudouresque 1996). The microsatellites used here (ArnaudHaond et al. 2013) allowed to increase the resolution power. The high polymorphism revealed in the native area allow the interpretation of the low diversity of MLGs sampled in the Mediterranean Sea (as well as in historical samples of the aborted invasion of California) as a likely outcome of the restricted diversity available in an aquarium acting as the source for the invasion. The perfect match in the identity of the MLG characterized from the aquarium and those in San Diego and some Mediterranean SUs confirms the origin of the Mediterranean and Californian strains as a single aquarium strain spread by commercial trade. Additionally, the genetic proximity of these invasive SUs with the ones sampled in Brisbane (Fig. 2) also supports an origin of this commercial aquarium strain closer to the populations of the southern part of the native range, as previously suggested on the basis of morphological and genetic singularities (Benzie et al. 2000; Fama et al. 2002; Meusnier et al. 2001; Meusnier et al. 2002; Meusnier et al. 2004; Schaffelke et al. 2002). Slightly different MLGs were also observed in the Mediterranean, suggesting that in addition to clonal growth, either somatic mutations or sexual recombination have occurred. The genetic difference affected a single locus and only one allele motif at a time, while heterozygosity was maintained in three other loci, favoring somatic

This article is protected by copyright. All rights reserved. 
mutations in the populations established in the Mediterranean, consistent with the lack of observation of female gametes and sexual reproduction in the Mediterranean (Zuljevic \& Antolic 2000).

In contrast, much higher diversities were observed at both the host and endophytic bacterial compartment levels in the invaded lagoons of NSW (Table 1), where the origin and mechanism of the more recent introduction had thus far remained an open question due to the low power of ITS (Schaffelke et al. 2002). A first attempt to use Amplified Fragment Length Polymorphism (Murphy \& Schaffelke 2003) allowed preliminary inferences as to the origin of the samples from Port Jackson and Lake Conjola (NSW). Here, the joint profile of higher diversity and the dichotomy in the distribution of host genomes, similar to that of bacterial communities, clearly support multiple origins of the populations of NSW. Microsatellite data, strengthened by the remarkably analogous pattern observed for associated bacterial communities, support an origin of the Port Jackson population close to Townsville, as previously suspected on the basis of ITS analysis (Schaffelke et al. 2002), whereas the other algae from NSW show distinct signatures . These cluster further apart, at equivalent distances from samples collected in the Northern part of the native range and from Mediterranean specimens. However, the population from Narrawallee exhibits a slightly distinct pattern of higher genetic diversity, suggesting the possibility of distinct introductions in this inlet. Additional analyses of bacterial communities in the southern part of the native range would likely bring relevant information to narrow down the screening of the approximate origin of Southern NSW C. taxifolia, as the relatedness of the Port Jackson population to that in Townsville is supported by both microsatellite and bacterial data.

This article is protected by copyright. All rights reserved. 
This inference supports the hypothesis of several distinct events and likely vectors of introductions in NSW possibly via ship or aquaculture transfer, the two main vectors of marine introductions (Ruiz et al. 2000; Williams 2007). The heavy traffic of recreational boats in the area may favor the transport of algae in lakes and inlets (Schaffelke et al. 2002), and although ballast water does not seem to be a major vector of introduction for green algae (Williams \& Smith 2007), it may be efficient over short distances and may be considered as a plausible vector in the case of Port Jackson in particular. Finally, aquaculture transfer of shellfish is also a major source of invasion (Ruiz et al. 2000) that should not be discarded, given that many shellfish are commercialized along the Eastern coast of Australia, some of them, including Saccostrea glomerata, which is distributed from Queensland to New South Wales, having been subject to extensive translocation practices across hundreds of kilometers (Banks et al. 2006).

\section{Is the bacterial community part of the invasion process?}

Importantly, the footprint of the origin of introduced populations as well as the signature of the introduction events having affected the effective population size of the algae appear on the levels of diversity revealed both for the host genome and the endophytic bacterial communities. The epiphytic bacterial communities, clustering with sediment samples, seem to mainly deliver information on environmental conditions and bacteria acquired from the environment. In contrast, the distribution of endophytic communities exhibits a remarkable correspondence with that of genetic polymorphism of C. taxifolia. This high level of coherence (Table 1, Fig. 2) suggests that a significant part of the endophytic community is possibly submitted to some form of vertical transmission. The clonal mode of $C$. taxifolia has the peculiarity that vertical transmission can be ensured during the events of clonal spread and fragmentation. Even if the

This article is protected by copyright. All rights reserved. 
mechanism of transmission of bacteria during gamete release and sexual reproduction remains unknown, the similar heterogeneity and differentiation of host and bacterial communities in the sister lagoons and inlets of NSW supports a co-introduction of part of the endophytic bacterial communities. Such coherence between the distributions of host and bacterial lineages, show that endophytic communities thus have the potential to play an active role in the successful establishment and spread of C. taxifolia in invaded areas.

The success of C. taxifolia as an invader has been attributed to a number of traits, such as its capacity for vegetative proliferation and fragmentation (Ceccherelli \& Cinelli 1999; Smith \& Walters 1999), a strong resistance to desiccation (Schaffelke \& Deane 2005) and low palatability to local predators (Gollan \& Wright 2006) in line with the ERH, all likely to improve the competitiveness of C. taxifolia. Additionally, its role as an engineer species inducing sharp habitat modifications both in the Mediterranean (Chisholm \& Moulin 2003; Holmer et al. 2009) and in Southern Australia (Byers et al. 2010; Gallucci et al. 2012) likely plays an important role in the displacement of native species. In the Mediterranean, the capacity to grow on anoxic sediment rich in organic matter, hydrogen sulfide and inorganic phosphorous (Chisholm et al. 1996), and to induce in turn changes in the sediment, may be related to the function of rhizoids as 'root-like' systems associated with specific bacterial lineages that induce enhanced nutrient fixation (Chisholm et al. 1996; Chisholm \& Moulin 2003; Holmer et al. 2009). This physiological peculiarity may also explain the release of organic matter stimulating sulfate reducers, which yields sulfides highly toxic to their seagrass competitors (Holmer et al. 2009).

This article is protected by copyright. All rights reserved. 
Data here are limited to partial $16 \mathrm{~S}$ characterization, which, together with the lack of in situ labeling or experimental cross-validation, only allows indirect inferences and preliminary hypotheses on the metabolism of OTUs exhibiting the best BLAST alignment. As a preliminary step, we compared the bacterial functions of the closest relative presenting the highest BLAST scores with some known sediment particularities in presence of Caulerpa sp. in the Mediterranean, including anoxia, phosphate precipitation and discharge in waste water (Chisholm et al. 1997), as well as enhanced rates of nitrogen fixation and high sulfide invasion (Chisholm \& Moulin 2003; Holmer et al. 2009). Chisholm et al. (1996) suggested that endocellular bacteria could allow the rhizoids of $C$. taxifolia to function as roots, providing it with the ability to take up organic and inorganic nutrients from sediments and potentially facilitating the removal of toxic sulfide while enhancing $\mathrm{N}_{2}$ fixation. Our screening of endophytic communities revealed a large prevalence of OTUs assigned to bacteria classically known as $\mathrm{N}_{2}$-fixing.

The two most prevalent and ubiquitous OTUs in epiphytic communities in the three regions belong to the Burkholderiales and Pseudomonadales. Their closest cultured relatives according to BLAST being respectively, Alicycliphilus denitrificans (type strain K601) a nitrate-reducing betaproteobacterium able to grow in anaerobic conditions (Dullius et al. 2011; Mechichi et al. 2003), and Acinetobacter sp., encompassing bacteria promoting plant growth via different mechanisms, including nitrogen fixation. The latter showed a clustering of lineages partly in line with that of their host, with haplotypes shared between the native area and the Mediterranean but also with Port Jackson (Fig. 4), whereas a secondary and smaller cluster characterize most NSW samples. Such tightly associated OTUs may be useful tracers of the origin of invasion, provided

This article is protected by copyright. All rights reserved. 
an improved sampling of the native area. Interestingly, the "Alicycliphilus denitrificans-like"

OTU is the sister OTU of the one identified on Caulerpa racemosa, that showed a segregation of haplotypes according to their host variety (Aires et al. 2013). Despite strict segregation of these OTU haplotypes at the species and variety levels, no differentiation was observed here among geographic regions, possibly due to larger effective population size than Acetinobacter sp. or to a different mode of transmission. Together with their absence in control samples, these results suggest a tight association of host with endophytic lineages whose putative function presents a remarkable analogy with the characterized upheaval in sediments in the invaded areas (Chisholm et al. 1996; Chisholm \& Moulin 2003; Holmer et al. 2009), causing the displacement of many native species (Ceccherelli \& Cinelli 1997; Garcias-Bonet et al. 2008).

\section{The holobiont concept to better understand the process of invasion}

The results reveal a tight association between the eukaryotic genome and the prokaryotic compartments, suggesting the heritability of part of the bacterial community and confirming its potential as a marker of the origin and path of dispersal (Meusnier et al. 2001; Nieberding \& Olivieri 2007). A consequence of this association, together with the putative function of bacteria, is their possible role in the "species"-based mechanisms (such as ERH and EICA, mentioned above) of invasion. This would support the Accompanying Hypothesis (Klock et al. 2015; Rodriguez-Echeverria 2010) to hold true for a broad part of the endophytic community. These results are also in line with recent synthesis underlining the ecological influence of bacteria on marine organisms (Wahl et al. 2012). Our results suggest that these species-based mechanisms must be reconsidered in terms of invasive "meta-organisms" or "holobionts" rather than single

This article is protected by copyright. All rights reserved. 
species because functions performed by endophytic bacteria may have facilitated the establishment and spread of Caulerpa taxifolia in the areas where it was introduced.

In conclusion, the results presented here support the use of the Accompanying Mutualist Hypothesis to describe, at the scale of the holobiont, the mutualistic relationship between Caulerpa taxifolia and its endophytic bacterial community during the course of invasion. The spread of the incidentally escaped aquarium strain of the green algae in the Mediterranean was initially presented as an archetype of the genetic paradox of invasions (Frankham 2005; Roman \& Darling 2007). The present comprehensive analysis of diversity patterns based on the recent development of hyper-variable markers for the host genome and the unlocking of massive metagenomic characterization of the endophytic bacterial communities made it a triple paradox at the holobiont scale: genotypic (with a single clone), genetic (this clonal lineage logically resulting in limited allelic diversity), and endophytic (extremely reduced diversity of bacterial communities compared to the native area). The paradox, however, may well be lost, or it may not last more than several decades at least in the case of C. taxifolia: since 2004, the species once called "killer algae" has vanished from several localities (Ivesa et al. 2006; Meinesz et al. 2010; Montefalcone et al. 2015; Tejada \& Sureda 2013), and the surface covered has regressed by approximately $80 \%$. This contrasts with the present state in NSW, where the more variable introduced populations currently show no sign of decline, approximately 15 years after their introduction. Among the main speculations that can be proposed to explain the Mediterranean regression, the poor resistance to temperature variations (particularly to cold winters), the genetic degeneration of the clonally spread host and the emergence of an antagonistic bacterial or virus strain may have affected the holobiont. Insufficient phenotypic plasticity, genetic degeneration

This article is protected by copyright. All rights reserved. 
and susceptibility to changes in abiotic and biotic environments are indeed more likely in a drastically impoverished genetic lineage, considering the genetic background of both the host and the symbionts. This regression is relatively recent and may be temporary. If the reason underlying the failure of the invasion is associated with the low diversity in distinct compartments, there may be greater impacts of a newly introduced variety recently discovered in Turkey and Italy (Jongma et al. 2013; Turan et al. 2011), C. taxifolia var. distichophylla, which is morphologically similar and extremely close genetically to the large male clone present in the Mediterranean for the past three decades, and the newly introduced variety is more diverse (Jongma et al. 2013). Moreover, if interbreeding occurs, a very possible event considering their morphological and genetic proximity (Jongma et al. 2013), this variety may also provide a genetic and/or bacterial rescue to the initially isolated holobiont clone.

\section{Acknowledgments}

We thank the diving team from the Villefranche marine station, particularly David Luquet, for the collection of samples from Villefranche and Habib Langar for those from Tunis, as well as Gary Kendricks, Nicholas Paul, Scott Seymour, Dean Jerry, Kor van Dijk, Michèle Waycott and Martin Billingham for help in collecting the Australian samples. This work was supported by the project IBISA (PTDC / MAR / 64749 / 2006) funded by the Portuguese Foundation for Science and Technology (FCT) and FEDER and by a PhD fellowship (TA) from FCT and FSE, and by the French ANR project CLONIX (ANR-11-BSV7-0007).

This article is protected by copyright. All rights reserved. 


\section{References}

Aires T, Marba N, Serrao EA, Duarte CM, Arnaud-Haond S (2012) Selective elimination of chloroplast in the green algae Caulerpa taxifolia: a cost efficient method to unlock the problem of enrichment for metagenomics? Journal of Phycology 48, 483-490.

Aires T, Serrao EA, Kendrick G, Duarte CM, Arnaud-Haond S (2013) Invasion is a community affair: clandestine followers in the bacterial community associated to green algae, Caulerpa racemosa, track the invasion source. PLoS One 8, e68429.

Anderson LWJ (2005) California's reaction to Caulerpa taxifolia: A model for invasive species rapid response. Biological Invasions 7, 1003-1016.

Arnaud-Haond S, Alberto F, Teixeira S, et al. (2005) Assessing genetic diversity in clonal organisms: Low diversity or low resolution? Combining power and cost efficiency in selecting markers. Journal of Heredity 96, 434-440.

Arnaud-Haond S, Belkhir K (2007) GENCLONE: a computer program to analyse genotypic data, test for clonality and describe spatial clonal organization. Molecular Ecology Notes 7, 15-17.

Arnaud-Haond S, Candeias R, Serrao EA, Teixeira SJL (2013) Microsatellite markers developed through pyrosequencing allow clonal discrimination in the invasive alga Caulerpa taxifolia. Conservation Genetics Resources 5, 667-669.

Arnaud-Haond S, Duarte CM, Alberto F, Serrão EA (2007) Standardizing methods to address clonality in population studies. Molecular Ecology 16, 5115-5139.

Banks SC, Piggott MP, Raftos DA, Beheregaray LB (2006) Microsatellite markers for the Sydney rock oyster, Saccostrea glomerata, a commercially important bivalve in southeastern Australia. Molecular Ecology Notes 6, 856-858.

Barrett SCH (2015) Foundations of invasion genetics: the Baker and Stebbins legacy INTRODUCTION. Molecular Ecology 24, 1927-1941.

Belkhir K, Borsa P, Chikhi L, Raufaste N, Bonhomme F (1996-2001) GENETIX 4.02, logiciel sous Windows TM pour la génétique des populations Laboratoire Génome et Populations, Interactions, Adaptations, CNRS UMR5000, Université Montpellier II, Montpellier, France.

BellanSantini D, Arnaud PM, Bellan G, Verlaque M (1996) The influence of the introduced tropical alga Caulerpa taxifolia, on the biodiversity of the Mediterranean marine biota. Journal of the Marine Biological Association of the United Kingdom 76, 235-237.

Benzie JAH, Ballment E, Chisholm JRM, Jaubert JM (2000) Genetic variation in the green alga Caulerpa taxifolia. Aquatic Botany 66, 131-139.

Blossey B, Notzold R (1995) Evolution of Increased Competitive Ability in Invasive Nonindigenous Plants - a Hypothesis. Journal of Ecology 83, 887-889.

Boudouresque CF, Bernard G, Pergent G, Shili A, Verlaque M (2009) Regression of Mediterranean seagrasses caused by natural processes and anthropogenic disturbances and stress: a critical review. Botanica Marina 52, 395-418.

Bowcock AM, Ruiz-Linares A, Tomfohrde J, et al. (1994) High resolution of human evolutionary trees with polymorphic microsatellites. Nature 368, 455-457.

Byers JE, Wright JT, Gribben PE (2010) Variable direct and indirect effects of a habitatmodifying invasive species on mortality of native fauna. Ecology 91, 1787-1798.

Caporaso JG, Kuczynski J, Stombaugh J, et al. (2010) QIIME allows analysis of high-throughput community sequencing data. Nature Methods 7, 335-336.

This article is protected by copyright. All rights reserved. 
Ceccherelli G, Cinelli F (1997) Short-term effects of nutrient enrichment of the sediment and interactions between the seagrass Cymodocea nodosa and the introduced green alga Caulerpa taxifolia in a Mediterranean bay. Journal of Experimental Marine Biology and Ecology 217, 165-177.

Ceccherelli G, Cinelli F (1999) The role of vegetative fragmentation in dispersal of the invasive alga Caulerpa taxifolia in the Mediterranean. Marine Ecology-Progress Series 182, 299303.

Chisholm JRM, Dauga C, Ageron E, Grimont PAD, Jaubert JM (1996) 'Roots' in mixotrophic algae. Nature 381, 382-382.

Chisholm JRM, Fernex FE, Mathieu D, Jaubert JM (1997) Wastewater discharge, seagrass decline and algal proliferation on the Cote d'Azur. Marine Pollution Bulletin 34, 78-84.

Chisholm JRM, Moulin P (2003) Stimulation of nitrogen fixation in refractory organic sediments by Caulerpa taxifolia (Chlorophyta). Limnology and Oceanography 48, 787-794.

Delbridge L, Coulburn J, Fagerberg W, Tisa LS (2004) Community profiles of bacterial endosymbionts in four species of Caulerpa. Symbiosis 37, 335-344.

Doyle JJ, Doyle JLI (1987) A rapid DNA isolation procedure for small quantities of fresh leaf tissue. Phytochemistry Bulletin 11, 11-15.

Dullius CH, Chen CY, Schink B (2011) Nitrate-Dependent Degradation of Acetone by Alicycliphilus and Paracoccus Strains and Comparison of Acetone Carboxylase Enzymes. Applied and Environmental Microbiology 77, 6821-6825.

Facon B, Genton BJ, Shykoff J, et al. (2006) A general eco-evolutionary framework for understanding bioinvasions. Trends in Ecology \& Evolution 21, 130-135.

Fama P, Jousson O, Zaninetti L, et al. (2002) Genetic polymorphism in Caulerpa taxifolia (Ulvophyceae) chloroplast DNA revealed by a PCR-based assay of the invasive Mediterranean strain. Journal of Evolutionary Biology 15, 618-624.

Francour P, Harmelinvivien M, Harmelin JG, Duclerc J (1995) Impact of Caulerpa taxifolia colonization on the littoral ichthyofauna of north-western Mediterranean Sea: preliminary results. Hydrobiologia 301, 345-353.

Frankham R (2005) Invasion biology - Resolving the genetic paradox in invasive species. Heredity 94, 385-385.

Gallucci F, Hutchings P, Gribben P, Fonseca G (2012) Habitat alteration and community-level effects of an invasive ecosystem engineer: a case study along the coast of NSW, Australia. Marine Ecology-Progress Series 449, 95-U120.

Garcias-Bonet N, Marba N, Holmer M, Duarte CM (2008) Effects of sediment sulfides on seagrass Posidonia oceanica meristematic activity. Marine Ecology-Progress Series 372, $1-6$.

Glasby TM (2013) Caulerpa taxifolia in seagrass meadows: killer or opportunistic weed? Biological Invasions 15, 1017-1035.

Gollan JR, Wright JT (2006) Limited grazing pressure by native herbivores on the invasive seaweed Caulerpa taxifolia in a temperate Australian estuary. Marine and Freshwater Research 57, 685-694.

Holmer M, Marbà N, Lamote M, Duarte CM (2009) Deterioration of sediment quality in seagrass meadows (Posidonia oceanica) invaded by macroalgae (Caulerpa sp.). Estuaries and Coasts 32, 456-466.

This article is protected by copyright. All rights reserved. 
Ivesa L, Jaklin A, Devescovi M (2006) Vegetation patterns and spontaneous regression of Caulerpa taxifolia (Vahl) C. Agardh in Malinska (Northern Adriatic, Croatia). Aquatic Botany 85, 324-330.

Jongma DN, Campo D, Dattolo E, et al. (2013) Identity and origin of a slender Caulerpa taxifolia strain introduced into the Mediterranean Sea. Botanica Marina 56, 27-39.

Jousson O, Pawlowski J, Zaninetti L, Meinesz A, Boudouresque CF (1998) Molecular evidence for the aquarium origin of the green alga Caulerpa taxifolia introduced to the Mediterranean Sea. Marine Ecology-Progress Series 172, 275-280.

Kivelä M, Arnaud-Haond S, Saramäki J (2015) EDENetworks: A user-friendly software to build and analyse networks in biogeography, ecology and population genetics. Molecular Ecology Resources 15, 117-122.

Klock MM, Barrett LG, Thrall PH, Harms KE, van Kleunen M (2015) Host promiscuity in symbiont associations can influence exotic legume establishment and colonization of novel ranges. Diversity and Distributions 21, 1193-1203.

Marbà N, Díaz-Almela E, Duarte CM (2014) Mediterranean seagrass (Posidonia oceanica) loss between 1842 and 2009. Biological Conservation 176, 183-190.

Marba N, Duarte CM (2010) Mediterranean warming triggers seagrass (Posidonia oceanica) shoot mortality. Global Change Biology 16, 2366-2375.

McNeely JA (2006) As the world gets smaller, the chances of invasion grow. Euphytica 148, 515.

Mechichi T, Stackebrandt E, Fuchs G (2003) Alicycliphilus denitrificans gen. nov., sp. nov., a cyclohexanol-degrading, nitrate-reducing beta-proteobacterium. International Journal of Systematic and Evolutionary Microbiology 53, 147-152.

Meinesz A, Boudouresque CF (1996) On the origin of Caulerpa taxifolia in the Mediterranean Sea. Comptes Rendus De L Academie Des Sciences Serie Iii-Sciences De La Vie-Life Sciences 319, 603-613.

Meinesz A, Chancollon O, Cottalorda J-M (2010) Observatoire sur l'expansion de Caulerpa taxifolia et Caulerpa racemosa en Méditerranée : campagne janvier 2008 - juin 2010, p. 50 .

Meinesz A, Hesse B (1991) Introduction of the tropical alga Caulerpa taxifolia and its invasion of the Northwestern Mediterranean. Oceanologica Acta 14, 415-426.

Meusnier I, Olsen JL, Stam WT, Destombe C, Valero M (2001) Phylogenetic analyses of Caulerpa taxifolia (Chlorophyta) and of its associated bacterial microflora provide clues to the origin of the Mediterranean introduction. Molecular Ecology 10, 931-946.

Meusnier I, Valero M, Destombe C, et al. (2002) Polymerase chain reaction-single strand conformation polymorphism analyses of nuclear and chloroplast DNA provide evidence for recombination, multiple introductions and nascent speciation in the Caulerpa taxifolia complex. Molecular Ecology 11, 2317-2325.

Meusnier I, Valero M, Olsen JL, Stam WT (2004) Analysis of rDNA ITS1 indels in Caulerpa taxifolia (Chlorophyta) supports a derived, incipient species status for the invasive strain. European Journal of Phycology 39, 83-92.

Millar AJK (2004) New records of marine benthic algae from New South Wales, eastern Australia. Phycological Research 52, 117-128.

Mitchell CE, Agrawal AA, Bever JD, et al. (2006) Biotic interactions and plant invasions. Ecology Letters 9, 726-740.

This article is protected by copyright. All rights reserved. 
Mitchell CE, Power AG (2003) Release of invasive plants from fungal and viral pathogens. Nature 421, 625-627.

Moalic Y, Arnaud-Haond S, Perrin C, Pearson G, Serrao E (2011) Travelling in time with networks: revealing present day hybridization versus ancestral polymorphism between two species of brown algae, Fucus vesiculosus and F. spiralis. BMC Evolutionary Biology $11,33$.

Montefalcone M, Morri C, Parravicini V, Bianchi CN (2015) A tale of two invaders: divergent spreading kinetics of the alien green algae Caulerpa taxifolia and Caulerpa cylindracea. Biological Invasions 17, 2717-2728.

Murphy NE, Schaffelke B (2003) Use of amplified fragment length polymorphism (AFLP) as a new tool to explore the invasive green alga Caulerpa taxifolia in Australia. Marine Ecology-Progress Series 246, 307-310.

Nieberding CM, Olivieri I (2007) Parasites: proxies for host genealogy and ecology? Trends in Ecology \& Evolution 22, 156-165.

Odom RL, Walters LJ (2014) A safe alternative to invasive Caulerpa taxifolia (Chlorophtya)? Assessing aquarium-release invasion potential of aquarium strains of the macroalgal genus Chaetomorpha (Chlorophyta). Biological Invasions 16, 1589-1597.

Parker MA (2001) Mutualism as a constraint on invasion success for legumes and rhizobia. Diversity and Distributions 7, 125-136.

Puth LM, Post DM (2005) Studying invasion: have we missed the boat? Ecology Letters 8, 715 721.

Richardson DM, Allsopp N, D'Antonio CM, Milton SJ, Rejmanek M (2000) Plant invasions--the role of mutualisms. Biological Reviews 75, 65-93.

Rius M, Turon X, Bernardi G, Volckaert FAM, Viard F (2014) Marine invasion genetics: from spatio-temporal patterns to evolutionary outcomes. Biological Invasions 17, 869-885.

Rodriguez-Echeverria S (2010) Rhizobial hitchhikers from Down Under: invasional meltdown in a plant-bacteria mutualism? Journal of Biogeography 37, 1611-1622.

Rodriguez-Echeverria S, Le Roux JJ, Crisostomo JA, Ndlovu J (2011) Jack-of-all-trades and master of many? How does associated rhizobial diversity influence the colonization success of Australian Acacia species? Diversity and Distributions 17, 946-957.

Roman J, Darling JA (2007) Paradox lost: genetic diversity and the success of aquatic invasions. Trends in Ecology \& Evolution 22, 454-464.

Rozenfeld AF, Arnaud-Haond S, Hernández-García E, et al. (2008) Network analysis identifies weak and strong links in a metapopulation system. Proceedings of the National Academy of Sciences 105, 18824-18829.

Ruiz GM, Fofonoff PW, Carlton JT, Wonham MJ, Hines AH (2000) Invasion of coastal marine communities in North America: Apparent patterns, processes, and biases. Annual Review of Ecology and Systematics 31, 481-531.

Sakai AK, Allendorf FW, Holt JS, et al. (2001) The population biology of invasive species. Annual Review of Ecology and Systematics 32, 305-332.

Schaffelke B, Deane D (2005) Desiccation tolerance of the introduced marine green alga Codium fragile ssp tomentosoides - clues for likely transport vectors? Biological Invasions 7, 557 565.

Schaffelke B, Murphy N, Uthicke S (2002) Using genetic techniques to investigate the sources of the invasive alga Caulerpa taxifolia in three new locations in Australia. Marine Pollution Bulletin 44, 204-210.

This article is protected by copyright. All rights reserved. 
Smith CM, Walters LJ (1999) Fragmentation as a strategy for Caulerpa species: Fates of fragments and implications for management of an invasive weed. Marine EcologyPubblicazioni Della Stazione Zoologica Di Napoli I 20, 307-319.

Tejada S, Sureda A (2013) A new approach using biomarkers to elucidate the regression state of the invasive alga Caulerpa taxifolia in waters around the Balearic Islands (Western Mediterranean Sea). Marine and Freshwater Research 64, 986-991.

Torchin ME, Lafferty KD, Dobson AP, McKenzie VJ, Kuris AM (2003) Introduced species and their missing parasites. Nature 421, 628-630.

Torchin ME, Mitchell CE (2004) Parasites, pathogens, and invasions by plants and animals. Frontiers in Ecology and the Environment 2, 183-190.

Turan G, Tekogul H, Cirik S, Meinesz A (2011) First record of the invasive green seaweed Caulerpa taxifolia (Bryopsidales) on the coast of Turkey. Cryptogamie Algologie 32, 379-382.

Vitousek PM, Dantonio CM, Loope LL, Rejmanek M, Westbrooks R (1997) Introduced species: A significant component of human-caused global change. New Zealand Journal of Ecology 21, 1-16.

Wahl M, Goecke F, Labes A, Dobretsov S, Weinberger F (2012) The second skin: ecological role of epibiotic biofilms on marine organisms. Front Microbiol 3, 292.

Wang Y, Qian P-Y (2009) Conservative fragments in bacterial 16S rRNA genes and primer design for 16S ribosomal DNA amplicons in metagenomic studies. PLoS One 4, e7401.

Williams SL (2007) Introduced species in seagrass ecosystems: Status and concerns. Journal of Experimental Marine Biology and Ecology 350, 89-110.

Williams SL, Smith JE (2007) A global review of the distribution, taxonomy, and impacts of introduced seaweeds. Annual Review of Ecology, Evolution, and Systematics 38, 327 359.

Wright JT, McKenzie LA, Gribben PE (2007) A decline in the abundance and condition of a native bivalve associated with Caulerpa taxifolia invasion. Marine and Freshwater Research 58, 263-272.

Zuljevic A, Antolic B (2000) Synchronous release of male gametes of Caulerpa taxifolia (Caulerpales, Chlorophyta) in the Mediterranean Sea. Phycologia 39, 157-159.

\section{Data Accessibility}

Metadata for bacterial communities were submitted to The European Nucleotide Archive (ENA) in the Sequence Read Archive (SRA) and are available under the accession number ERP003250. http://www.ebi.ac.uk/ena/data/view/PRJEB3998. They include the sequence files together with the primers and tag file (i.e. "mapping file"). Data of genotypes of caulerpa taxifolia are available in Dryad (http://dx.doi.org/10.5061/dryad.116q7). They are composed an excel file containing metadata and genotypes for microsatellites.

This article is protected by copyright. All rights reserved. 


\section{Author Contributions}

SAH, MV and ES designed the study, SAH and TA performed the sampling, SAH, TA, RC and

SJL produced the data, SAH and TA analyzed data, all authors contributed to their interpretation,

SAH and TA wrote with CMD, MV and ES wrote and edited the manuscript

\section{Tables}

Table 1. Details of the samples collected, with the number of sampling units $(\mathrm{N})$, year of collection, approximate depth, approximate area sampled, number of distinct MLGs discriminated $(\mathrm{G})$ standardized for the lowest number of samples (13) in locations where more than 10 sampling units were collected, standardized $(\hat{A})$ allelic richness, and number of estimated OTUs ( $\mathrm{Sp}$ ) also standardized for the lowest number of sequences obtained among samples.

\begin{tabular}{|c|c|c|c|c|c|c|c|c|c|c|c|}
\hline \multirow[b]{2}{*}{ Region } & \multirow[b]{2}{*}{ Location } & \multicolumn{2}{|r|}{ Yea } & \multirow{2}{*}{$\begin{array}{l}\text { App. } \\
\text { depth }\end{array}$} & \multirow{2}{*}{$\begin{array}{l}\text { App. } \\
\text { area }\end{array}$} & \multirow[b]{2}{*}{$\hat{\mathbf{G}}$} & \multirow[b]{2}{*}{$\mathbf{R}$} & \multirow[b]{2}{*}{ A } & \multicolumn{3}{|c|}{ Hn } \\
\hline & & $\mathbf{N}$ & $\mathbf{r}$ & & & & & & $\hat{\mathbf{A}}$ & b & Sp \\
\hline \multirow[t]{4}{*}{ NE Australia } & All & 44 & - & - & & 11.9 & 0.7 & 4 & 33.6 & 0.68 & 142 \\
\hline & Kelso Reef & 2 & 1999 & - & - & - & - & 1 & - & - & - \\
\hline & $\begin{array}{l}\text { Kissing } \\
\mathbf{n} \ldots \text {. }\end{array}$ & 23 & 2010 & $0-2$ & 1 & $\begin{array}{c}12.7 \\
1\end{array}$ & 0.9 & 2 & 22.4 & 0.43 & 661 \\
\hline & Brisbane & 19 & 1999 & - & - & 8.56 & 0.5 & $\frac{1}{\varepsilon}$ & $\begin{array}{c}14.8 \\
6\end{array}$ & 0.23 & - \\
\hline \multirow[t]{5}{*}{ SE Australia } & All & $\begin{array}{c}10 \\
n\end{array}$ & 2010 & - & & 4.33 & $\underset{n}{0.0}$ & 3 & $\begin{array}{c}24.2 \\
0\end{array}$ & & $\begin{array}{c}196 \\
\circ\end{array}$ \\
\hline & Port Jackson & 30 & 2010 & $2-6$ & 1 & 1.68 & 0.0 & $\begin{array}{l}1 \\
7\end{array}$ & $\begin{array}{c}14.1 \\
?\end{array}$ & 0.13 & 270 \\
\hline & $\begin{array}{l}\text { Lake } \\
r \ldots \ldots-1\end{array}$ & 30 & 2010 & $0-2$ & 1 & 1 & 0 & 1 & 14 & 0.38 & 625 \\
\hline & Narrawallee & 17 & 2010 & $0-2$ & 1 & 4.31 & $\begin{array}{c}0.2 \\
\varepsilon\end{array}$ & $\begin{array}{l}2 \\
1\end{array}$ & 22.2 & 0.46 & 696 \\
\hline & Burrill Lake & 32 & 2010 & $0-2$ & 1 & 4.95 & $\begin{array}{c}0.1 \\
\mathrm{n}\end{array}$ & $\begin{array}{l}1 \\
\circ\end{array}$ & $\begin{array}{c}16.6 \\
5\end{array}$ & 0.40 & 501 \\
\hline \multirow{5}{*}{ Mediterranea } & All & 38 & - & - & & 4.03 & $\begin{array}{c}0.1 \\
1\end{array}$ & $\begin{array}{l}1 \\
?\end{array}$ & $\begin{array}{c}12.9 \\
n\end{array}$ & 0.27 & 321 \\
\hline & Aquarium & 2 & - & - & - & - & - & $\begin{array}{l}1 \\
1\end{array}$ & - & - & - \\
\hline & Villefranche & 13 & 2009 & $11-16$ & $1-2$ & 4 & $\begin{array}{c}0.2 \\
\boldsymbol{z}\end{array}$ & 1 & 13 & 0.27 & 94 \\
\hline & Croatia & 1 & 1999 & - & - & - & - & 1 & - & - & - \\
\hline & Tunis & 22 & 2009 & $?$ & $1-1.5$ & 3.15 & $\underset{1}{0.1}$ & 1 & $\begin{array}{c}12.9 \\
n\end{array}$ & 0.27 & 120 \\
\hline \multirow[t]{2}{*}{ Pacific } & San Diego & 2 & 2000 & - & - & - & - & $\begin{array}{l}1 \\
1\end{array}$ & - & - & - \\
\hline & Tahiti & 2 & 1999 & - & - & - & - & 1 & - & - & - \\
\hline
\end{tabular}

This article is protected by copyright. All rights reserved. 


\section{Figure Captions}

Figure 1. Main sampling locations in Queensland (Blue; KP- Kissing Point/Townsville, KRKelso Reef, B- Brisbane), NSW (Green and brown, PJ- Port Jackson, LC- Lake Conjola, NNarrawallee, BL- Burrill Lake) and the Mediterranean (Orange, C- Croatia, V- Villefranche, TTunis). Color codes are standardized with figures illustrating the alpha and beta diversities of samples based on microsatellites for algae and metabarcoding for bacterial communities. The picture on the lower right shows a typical Mediterranean specimen of Caulerpa taxifolia, and some intermingled stolons of the also-invasive sister species $C$. racemosa can be seen in the background (credits Sophie Fallour).

Figure 2. (a) Network of multi-locus genotypes (MLGs) of Caulerpa taxifolia based on Allele Sharing Distance (percolation threshold $\mathrm{D}_{\mathrm{pe}}=1.25$ non-shared alleles per loci). Each dot represents a MLG, and links are tuned from light grey to black at decreasing distances among MLGs. The size of nodes is standardized except for MLGs encountered more than 5 times in the dataset (for New South Wales (NSW), 60 replicates were shared among BL, N, LC, and PJ; 30 replicates were collected from the Mediterranean, with 25 identical MLGs, including the samples from the aborted Californian invasion). (b) Network of endophytic microbial communities based on Bray Curtis Distance (percolation threshold, $\mathrm{D}_{\mathrm{pe}}=0.84$ ). For both networks, blue dots represent genes from the native Queensland (QLD) collected in Kelso Reef (turquoise), Townsville (dark blue) and Brisbane (light blue). Brown and green dots represent genes the invasive NSW (Brown for Port Jackson; light green for Narrawallee; dark green for both Lake Conjola and Burrill Lake, which share many MLGs). For the MLG network, orange dots in the Mediterranean encompassed an admixture of marginally distinct MLGs (1 single locus) mostly

This article is protected by copyright. All rights reserved. 
common, including the Aquarium Strain, circled in red. (c) Levels of clonal, genetic and bacterial diversity in QLD (blue), NSW (green) and the Mediterranean (orange). The number of OTUs is divided by 100 to allow it to be projected on the same axis as allelic richness.

Figure 3. Principal Component Analysis of bacterial communities. The panels illustrate the segregation for (a) the entire sample of microbial assemblages and (b) endophytic (disinfected) SUs only.

Figure 4 Haplotype network of the OTU assigned through BLAST to (a) Alicycliphilus denitrificans (Betaproteobacteria) and (b) Acinetobacter sp. (Gammaproteobacteria). Each dot represents a haplotype or a set of very closely related haplotypes merged by the star contraction algorithm. The length of links is approximately proportional to the nucleotidic distance among haplotypes but was slightly modified between the two dominant haplotypes (distinct by only one mutation) to improve visualization. The color code is identical to the sampling and network figures, with blue for Queensland, green and brown for NSW (brown for Port Jackson, light green for Narrawallee, and dark green for both Lake Conjola and Burill Lake), and orange for the Mediterranean.

This article is protected by copyright. All rights reserved. 


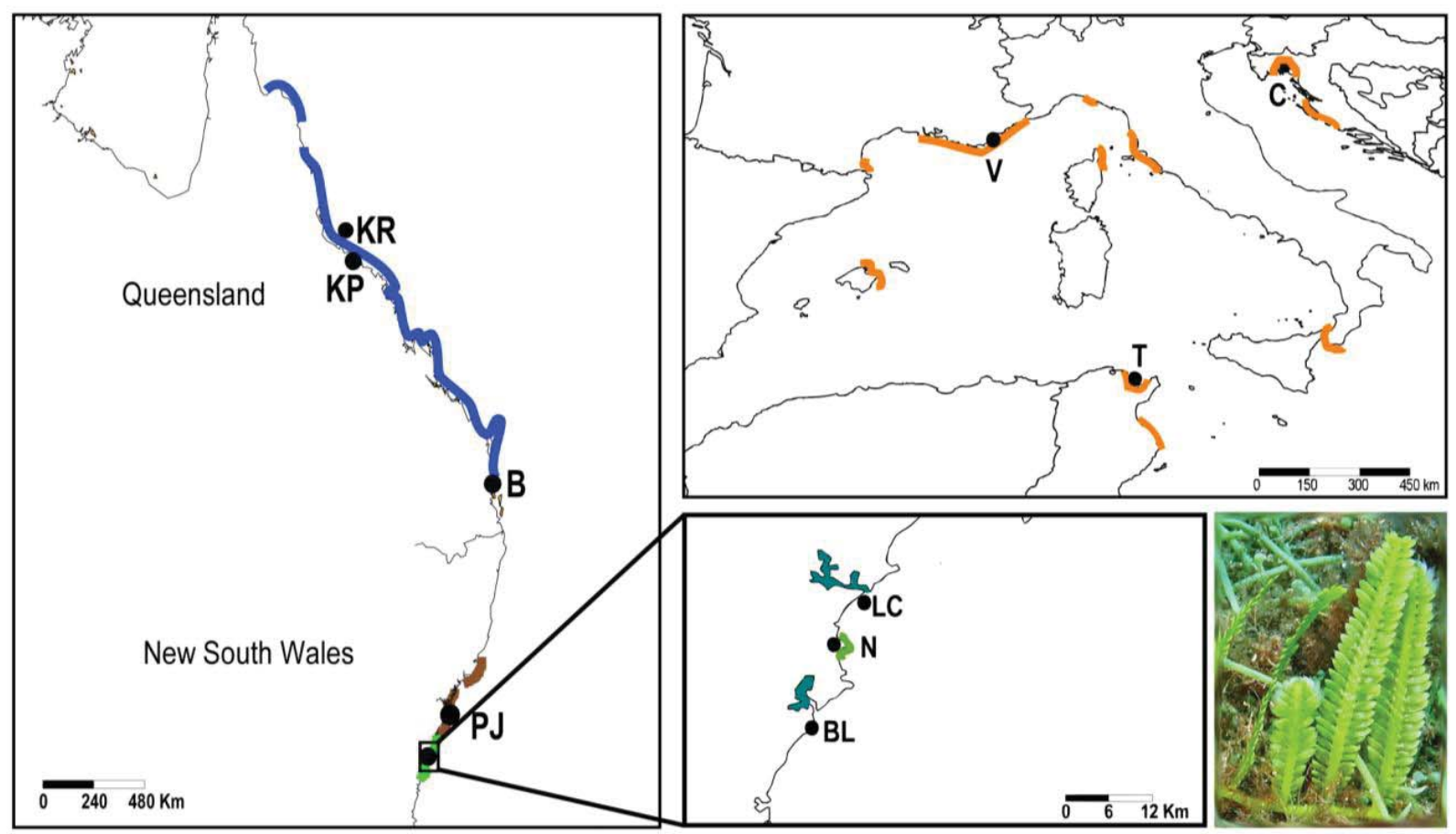

Lorem ipsum

a)

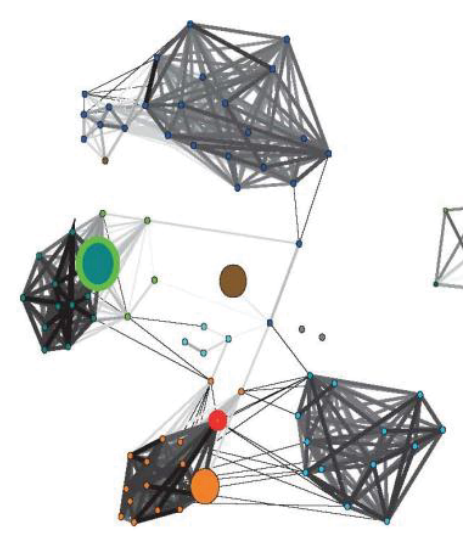

b)

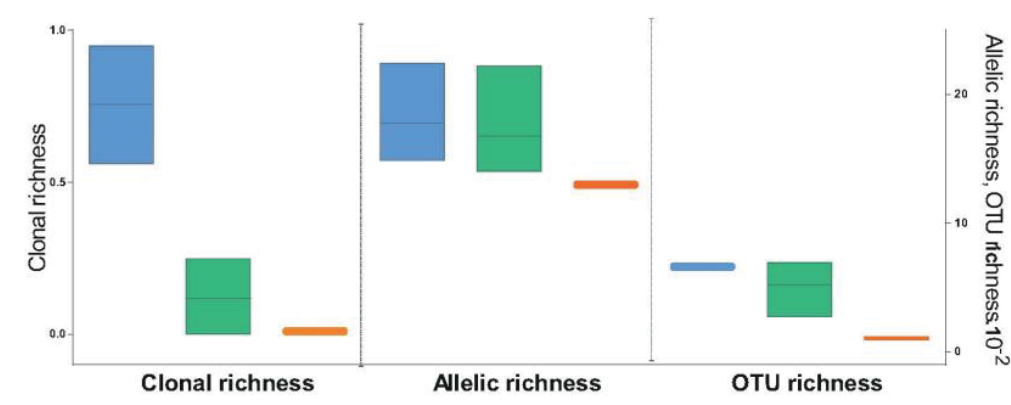

This article is protected by copyright. All rights reserved. 


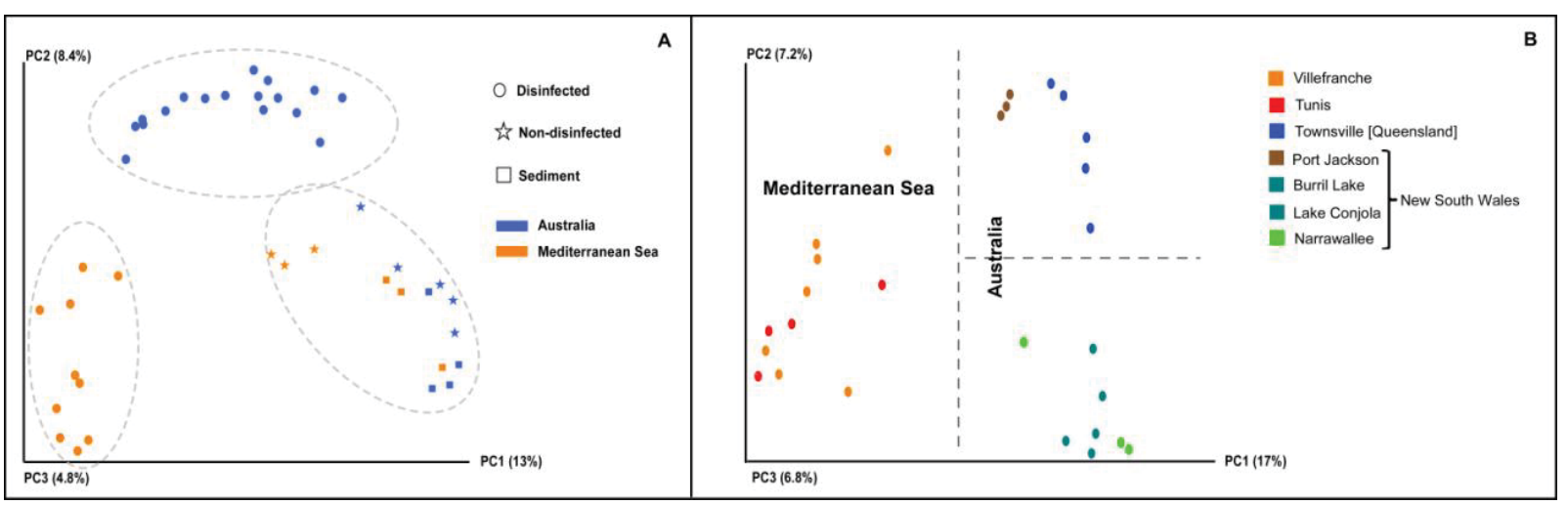

a)

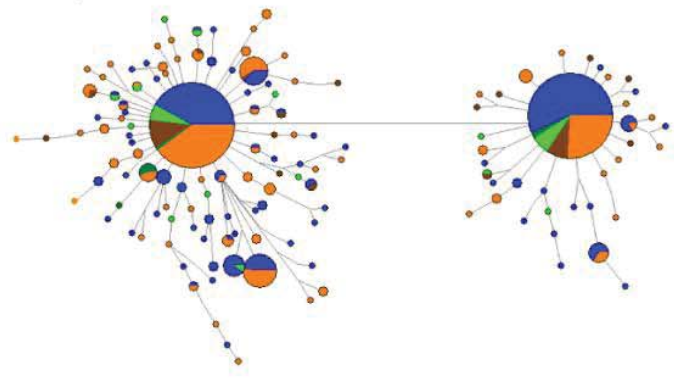

Mediterranean Sea

Townsville

- Port Jackson

Burril Lake \& Lake Conjola

Narrawallee

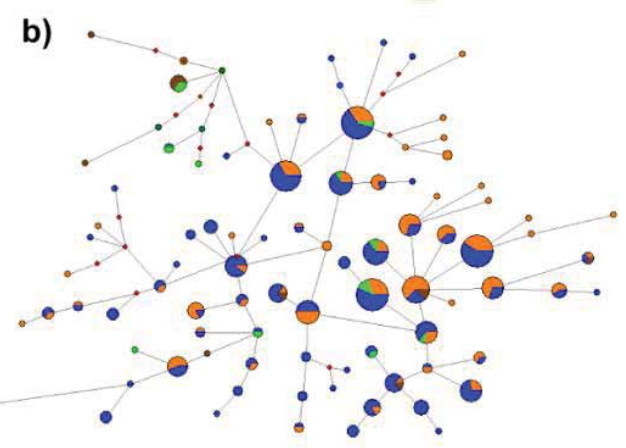

This article is protected by copyright. All rights reserved. 